\title{
Crenicichla chicha, a new species of pike cichlid (Teleostei: Cichlidae) from the rio Papagaio, upper rio Tapajós basin, Mato Grosso, Brazil
}

\author{
Henrique R. Varellaํㅗ Sven O. Kullander² and Flávio C. T. Lima ${ }^{3}$
}

Crenicichla chicha, new species, occurs in clear, fast-running waters with rocky substrates in the rio Papagaio and tributaries. It is distinguished from all other Crenicichla species by the combination of two character states: infraorbitals 3 and 4 coossified (vs. separated) and 66-75 scales in the row immediately above to that containing the lower lateral line (E1 row scales). Crenicichla chicha shares a smooth preopercular margin, co-ossification of infraorbitals 3 and 4, and some color features with C. hemera from the adjacent rio Aripuanã drainage, rio Madeira basin. It differs from Crenicichla hemera in more E1 scales (6675 vs. 58-65) and presence of a conspicuous black narrow stripe running from infraorbital 3 obliquely caudoventrad toward the preopercular margin $v$ s. a rounded and faint suborbital marking present on infraorbitals 3-4. Examination of the type series and additional material from the rio Aripuanã confirms that Crenicichla guentheri Ploeg, 1991 is a junior subjective synonym of $C$. hemera Kullander, 1990.

Crenicichla chicha, espécie nova, ocorre em águas claras, correntes e com substrato rochoso, no rio Papagaio e tributários. É distinta de todas as outras espécies de Crenicichla pela combinação de dois estados de caracteres: ossos infraorbitais 3 e 4 co-ossificados (vs. separados) e 66-75 escamas na série imediatamente superior àquela que contém a linha lateral posterior (série E1). Crenicichla chicha compartilha o pré-opérculo liso, a co-ossificação dos infraorbitais 3-4 e aspectos do colorido com Crenicichla hemera do rio Aripuanã, bacia do rio Madeira. Difere de C. hemera por possuir mais escamas na série E1 (6675 vs. 58-65) e uma listra suborbital preta e estreita, bem evidente, percorrendo obliquamente desde o infraorbital 3 até a margem do pré-opérculo vs. uma mancha suborbital arredondada e fraca situada nos infraorbitais 3-4. O exame da série típica e de material adicional proveniente do rio Aripuanã confirma que C. guentheri Ploeg, 1991 é um sinônimo júnior de C. hemera Kullander, 1990.

Key words: Crenicichla guentheri, Crenicichla hemera, Jacundá, Osteology, Rio Juruena.

\section{Introduction}

Crenicichla Heckel is considered to be the most species rich genus of South American cichlids, comprising 84 valid species (Kullander, 2003; Kullander \& Lucena, 2006; Casciotta et al., 2006; Lucena, 2007; Casciotta \& Almirón, 2008; Montaña et al., 2008; Kullander, 2009; Piálek et al., 2010; Casciotta et al., 2010). These fishes are popularly known in Brazil as "joaninhas", "peixes-sabão" and "jacundás” and are found over most river drainages of tropical to temperate cis-Andean South America (Kullander \& Lucena, 2006). Earlier revisions of the genus were made by Pellegrin (1904) and Regan (1905, 1913). The relatively recent revision of Crenicichla by Ploeg (1991), though an important contribution, is unfortunately plagued with several shortcomings and certainly cannot be considered a definitive monograph of the systematics of the genus. More recent taxonomic studies of the genus have been developed within a regional scope, restricted to river drainages or geographic units (e.g. Lucena \& Kullander, 1992; Kullander \& Lucena, 2006). The current knowledge of the phylogenetic relationships among Crenicichla and the related genus Teleocichla was recently summarized by Kullander $e t$ al. (2009). Overall, it can be concluded that there is still much research to be accomplished before a comprehensive view of the phylogenetic relationships within this large and morphologically diverse genus is reached.

Recent collecting activities in the rio Juruena, a major headwater of the rio Tapajós in the State of Mato Grosso, Brazil, revealed a distinctive, undescribed species of Crenicichla similar to C. hemera Kullander. The purpose of

${ }^{1}$ Museu de Zoologia da Universidade de São Paulo, Caixa Postal 42494, 04218-970 São Paulo, SP, Brazil. hrvarella@hotmail.com ${ }^{2}$ Department of Vertebrate Zoology, Swedish Museum of Natural History, POB 50007, SE-104 05 Stockholm, Sweden. sven.kullander@nrm.se

${ }^{3}$ Museu de Zoologia da Universidade Estadual de Campinas “Adão José Cardoso”, Caixa Postal 6109, 13083-970 Campinas, SP, Brazil. fctlima@gmail.com 
the present paper is primarily to describe this new species. Based on the comparative examination of extensive series of its putative close relative $C$. hemera, we also take this opportunity to provide additional diagnostic data and describe variation in that species. We also address the status of $C$. guentheri Ploeg, placed in the synonymy of $C$. hemera by Kullander (1997), based on the type series and a much larger material now available from the Aripuanã drainage.

\section{Material and Methods}

Specimens lengths are given as standard length (SL), measured from the tip of the upper jaw to the middle of the base of caudal fin. Measurements and counts were taken as described by Kullander (1986) and presented as percentages of SL. Counts from the holotype indicated by an asterisk (*). Scales in a longitudinal row (E1 scales row) are counted in the row immediately dorsal to that containing the lower lateral line. Color marking terminology follows Kullander (1986) and Kullander \& Lucena (2006). Vertebral counts and osteological notes on the new species were based on one specimen, $70.2 \mathrm{~mm}$ of SL (MZUSP 93683), cleared and stained following the method of Taylor \& van Dyke (1985). Vertebral counts include the last half-centrum. The lower pharyngeal tooth plate is measured as described by Barel et al. (1977). Illustrations of the pharyngeal tooth plate and the infraorbitals were based on the cleared and stained specimen, photographed under a stereomicroscope and further manipulated with image editor software.

Institutional abreviations: Asociación Ictiológica, La Plata, Argentina (AI); Instituto Nacional de Pesquisas da Amazônia, Manaus, Brazil (INPA); Museu de Ciências e Tecnologia, Pontifícia Universidade Católica do Rio Grande do Sul, Porto Alegre, Brazil (MCP); Museu de Zoologia da Universidade de São Paulo, Brazil (MZUSP); Swedish Museum of Natural History, Stockholm, Sweden (NRM); Núcleo de Pesquisa em Limnologia, Ictiologia e Aquicultura, Universidade Estadual de Maringá, Brazil (NUP) and Museu de Zoologia da Universidade Estadual de Campinas, Brazil (ZUEC).

\section{Crenicichla chicha, new species Figs. 1-6}

Holotype. MZUSP 109198,100.7 mm SL, Brazil, State of Mato Grosso, Sapezal, rio Tapajós drainage, rio Papagaio, about $3 \mathrm{~km}$ above road Sapezal/Tangará da Serra, 13³6’03”S 058²5’05”W, 11 Oct 2006, F. A. Machado, F. C. T. Lima, C. M. C. Leite \& N. E. Silva.

Paratypes. All from State of Mato Grosso, rio Tapajós basin, rio Papagaio drainage. ANSP 192028,1, 75.2 mm SL; MZUSP 93683, 7, 45.2-94.1 mm SL; 1 c\&s, 70.2 mm SL; NRM 61678,1, 82.2 mm SL; ZUEC 6359, 1, 70.9 mm SL: same data as holotype. MCP 39515, 4, 36.7-57.0 mm SL, Sapezal, rio Papagaio at Balneário do Pubi, 13³3’35”S 058²4’31”W, 13 Jul 2004, P. Lehmann, V. A. Bertaco, J. F. Pezzi, F. C. T. Lima \& F. Langeani. MCP 42663, 1, 115.2 mm SL, Sapezal, rio Papagaio, 13³3’16”S 058²4’25”W, 7 Mar 2007, V. Lampert \& M. Teixeira. MCP 42682, 1, 42.9 mm SL,
Campo Novo do Parecis, rio Sacre, 13³6’52”S 05805’38’W, 8 Mar 2007, V. Lampert \& M. Teixeira. MCP 42722, 1, 39.7 mm SL, Campo Novo do Parecis, rio Sacre, 13³6’52”S 05805’40”W, 6 Jul 2007, V. Lampert. MCP 45667, 1, 33.8 mm SL, Sapezal, Córrego Água Quente, road between Sapezal and the rio Papagaio, 13³2'25”S 058`43’32”W, 13 Jul 2004, R. E. Reis, P. A. Buckup, A. R. Cardoso \& E. H. L. Pereira. MZUSP 5182, 1, 76.2 mm SL; NRM 61677, 1, 73.9 mm SL: rio Papagaio, upstream of Salto de Utiariti, $13^{\circ} 01^{\prime} 30^{\prime \prime} \mathrm{S}$ 58¹6’38”'W, Nov 1966, K. Lenko \& P. Pereira. MZUSP 93510, 3, 48.4-137.7 mm SL; NRM 61679, 1, 57.7 mm SL: Sapezal, Ribeirão Vinte e Cinto de Maio, near its mouth, approximately 13035'47”S 58 25'27’W, 11-13 Oct 2006, F. A. Machado, F. C. T. Lima, C. M. C. Leite \& N. E. Silva. MZUSP 93678, 1, 97.2 mm SL, Sapezal, creek tributary of rio Papagaio, fazenda Savocal (near road to Brasnorte), 1247’02”'S 58²3'29”W, 9 Oct 2006, F. A. Machado, F. C. T. Lima, C. M. C. Leite \& N. E. Silva. MZUSP 107043, 1, 76.8 $\mathrm{mm}$ SL, Sapezal, rio Papagaio and mouth of rio Buriti, near bridge on road between Sapezal and Brasnorte, 1247'06”S 58 23'05”W, 7-9 Oct 2006, F. A. Machado, F. C. T. Lima, C. M. C. Leite \& N. E. Silva. NUP 11523, 2, 56.5-62.2 mm SL, Sapezal, rio Papagaio, 13³3'42”S 58²4'25”W, 17 Sep 2010, C. H. Zawadzki \& W. P. Troy. NUP 11566, 1, 79.7 mm SL, Campo Novo do Parecis, Balneário rio Verde, rio Verde, 13³7’8.66”S 580’51.99”W, 18 Sep 2010, C. H. Zawadzki \& W. P. Troy.

Diagnosis. An elongated and medium-sized species of Crenicichla (maximum SL known $137.7 \mathrm{~mm}$ ) with moderatesized scales on flanks. Crenicichla chicha can be easily distinguished from all species of Crenicichla by a set of character states in combination: 66-75 scales in E1 series; laterally compressed body (vs. cylindrical and robust body in most species of $C$. reticulata group); absence of a distinct humeral blotch (vs. presence in C. saxatilis group); smooth supracleithrum (vs. spiny projections on posterior margin of supracleithrum bone in C. wallacii group); smooth preopercular margin, absence of microbranchiospines and infraorbitals 3 and 4 co-ossified (vs. posterior margin of preopercle serrated or with irregular projections, microbranchiospines present on the $2^{\text {nd }}$ through $4^{\text {th }}$ gill arches and infraorbitals 3-4 separated in most Crenicichla species).

The co-ossification of the infraorbitals 3 and 4 is an uncommon character state shared only with Crenicichla hemera. These species also share other uncommon characteristics, as the smooth preopercle and absence of microbranchiospines, but the new species differs from $C$. hemera in the presence of 66-75 scales in E1 row (vs. 58-65), and by having a conspicuous narrow suborbital stripe running from infraorbital 3 obliquely caudoventrad toward preopercular margin (vs. suborbital marking rounded, situated on infraorbitals 3-4).

Description. Largest male 137.7 mm SL, largest female 97.2 mm SL. Morphometric data in Table 1.

Head slightly deeper than wide. Snout moderately long, rounded when viewed from above, bluntly pointed in lateral view. Lower jaw slightly prognathous, its articulation below middle of orbit; ascending premaxillary processes reaching to about $1 / 3$ of orbit diameter; maxilla almost reaching to vertical from anterior margin of orbit. 


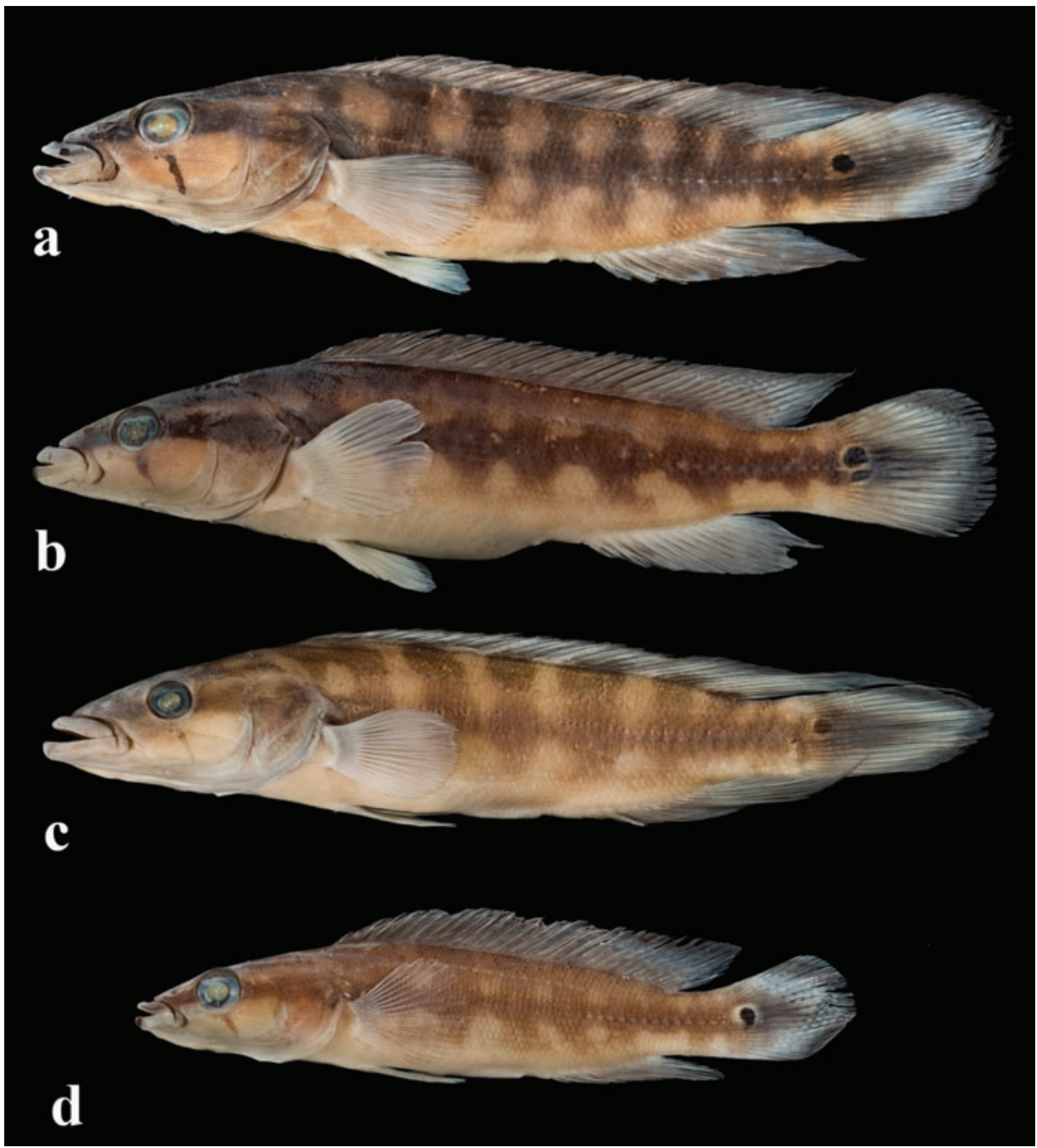

Fig. 1. Crenicichla chicha. (a) Holotype, MZUSP 109198, 100.7 mm SL, a male from rio Papagaio; (b) Paratype, MZUSP 93678, 97.2 mm SL, female, from a tributary of rio Papagaio; (c) Paratype, MZUSP 93510, 137.7 mm SL, male, from ribeirão Vinte e Cinto de Maio, tributary of rio Papagaio; (d) Paratype, MZUSP 93683, 61.4 mm SL, juvenile, from ribeirão Vinte e Cinco de Maio, tributary of rio Papagaio. 
Table 1. Standard length in millimeters and proportional measurements in percents of standard length of Crenicichla chicha. $\mathrm{N}$ = number of specimens, SD = standard deviation; holotype measurements are also contained in the sample range.

\begin{tabular}{|c|c|c|c|c|c|c|}
\hline & \multirow[b]{2}{*}{ Holotype } & \multicolumn{5}{|c|}{ Range } \\
\hline & & $\mathrm{N}$ & Min & Max & Mean & SD \\
\hline Standard length (mm) & 100.7 & 28 & 33.8 & 137.7 & 68.8 & - \\
\hline Body depth & 22.1 & 28 & 19.4 & 22.7 & 21.0 & 0.8 \\
\hline Head length & 34.7 & 28 & 30.0 & 34.7 & 32.2 & 1.0 \\
\hline Head depth & 15.3 & 28 & 13.7 & 16.0 & 14.8 & 0.6 \\
\hline Orbital diameter & 9.1 & 28 & 7.4 & 13.1 & 9.7 & 1.4 \\
\hline Interorbital width & 4.9 & 28 & 3.5 & 5.2 & 4.4 & 0.3 \\
\hline Snout length & 8.8 & 28 & 6.4 & 10.6 & 8.1 & 0.9 \\
\hline Upper jaw length & 9.9 & 27 & 6.4 & 10.3 & 8.3 & 0.9 \\
\hline Lower jaw length & 14.9 & 27 & 11.6 & 14.9 & 13.4 & 0.8 \\
\hline Caudal peduncle depth & 10.4 & 28 & 9.2 & 10.9 & 10.1 & 0.4 \\
\hline Caudal peduncle length & 13.1 & 27 & 11.2 & 17.4 & 13.3 & 1.2 \\
\hline Last dorsal spine length & 9.9 & 25 & 8.0 & 13.1 & 11.1 & 1.2 \\
\hline Pectoral fin length & 19.1 & 26 & 16.9 & 20.9 & 19.1 & 0.9 \\
\hline
\end{tabular}

Lips thick and wide, lower lip folds separate anteriorly; folds of upper lip not continuous but cutting into a symphyseal thickening. Postlabial skin fold margin truncate. Orbit supralateral, not visible from below, almost entirely in anterior half of head. Interorbital area flat, narrower than mouth. Nostril dorsolateral, about halfway between orbit and margin of postlabial skin fold, with low tubular margin but no anterior marginal membranaceous skin flap. No preopercular or other serrations on head bones, neither on supracleithrum. Lateralis pores on head simple or with two small openings, easily visible. Infraorbitals 3 and 4 co-ossified, with a median opening (Fig. 2).

Flank scales weakly ctenoid. All scales cycloid on head, on dorsum above anterior half of upper lateral line, along dorsal-fin base, on chest, and on belly below line from lower edge of pectoral-fin base to anal-fin origin. Predorsal scales small, embedded in skin, extending forward to transverse frontal lateralis canal; prepelvic scales slightly smaller than predorsal ones. Cheek completely scaled, about 6-9 horizontal scale rows below orbit, superficially embedded in skin. Interopercle naked or with a patch of 1-3 scales posteriorly, embedded in skin.

Scales in E1 row 66 (2), 68 (5), 69 (5*), 70 (3), 71 (5), 72 (3), 73 (3), 74 (1), or 75 (1). Transverse scale row $15-18+1+5-6$. Circumpeduncular scale rows 11-12 dorsally, 11-13 ventrally (24-27 including lateral lines).

Lateral-line scales 21/12 (1), 22/11 (1), 22/12 (1), 22/13 (1), 23/11 (2), 23/12 (9*), 23/13 (2), 24/11 (3), 24/12 (6), or 24/13 (2), and 1-3 scales continuing lower line onto caudal fin. Upper lateral line overlapping lower by one scale or not. Scales between upper lateral line and dorsal fin 12-13 anteriorly, 4-5 posteriorly; scale rows between lateral lines 3-4. Anterior upper lateral-line scales larger and more elongate than adjacent scales, remaining lateral-line scales nearly same size as adjacent scales; 3-4 scales impinging on each scale of anterior part, two on each scale of posterior part of upper lateral line; 1-2 scales impinging on each scale of lower lateral line.

Dorsal, anal, pectoral, and pelvic fins without scales. Caudal-fin squamation extending to about $1 / 3$ of fin, posterior margin of scaled area straight.
First dorsal-fin spine about 1/4 length of last; spines subequal in length from 8-10 $0^{\text {th. }}$ Soft part of dorsal fin with subacuminate tip, reaching to base of caudal fin or slightly beyond in immature males and females. In mature males (MZUSP 93510, $137.7 \mathrm{~mm}$; MCP 42663, $115.2 \mathrm{~mm}$, and MZUSP $93683,100.7 \mathrm{~mm}), 6-12^{\text {th }}$ soft dorsal rays elongated, $9^{\text {th }}$ and $10^{\text {th }}$ reaching level of middle caudal fin or even surpassing its distal margin. Dorsal-fin count XIX.14 (3), XIX.15(1), XX.13 (3), XX.14(15*), XX.15(4), XXI.13(1).

Soft anal fin with subacuminate tip, $7^{\text {th }}$ ray longest, reaching slightly beyond caudal fin base; largest male (MZUSP 93510) with the $7^{\text {th }}$ and $8^{\text {th }}$ rays more elongated, reaching to half of caudal fin. Skin of anterior soft rays, lappets and proximal margin of soft portion thickened. Anal fin count III.10 (1*), III.11 (2), III.12 (22), III.13 (1), IV. 10 (1). Caudal fin rounded to sublanceolated. Pectoral fin rounded, 7th ray longest, reaching about halfway to first to third anal spine. Pectoral-fin rays 17 (13), $18\left(14^{*}\right)$. Pelvic fin inserted slightly posteriorly to vertical from pectoral axilla, with rounded or subacuminate tip, second ray longest, reaching about halfway to spinous anal fin.

All teeth pointed, slightly recurved, teeth in outer row fixed,

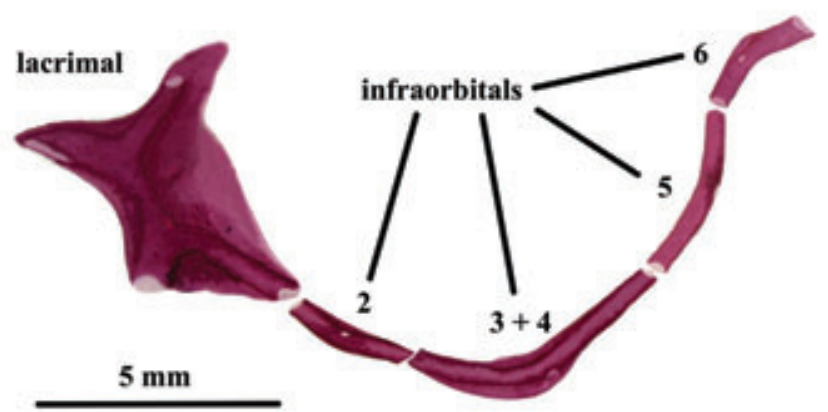

Fig. 2. Lacrimal and infraorbital series of Crenicichla chicha, lateral view of the left side (MZUSP 93683, $70.2 \mathrm{~mm} \mathrm{SL}$ ). Note that infraorbitals 3 and 4 are co-ossified, with a median opening. 

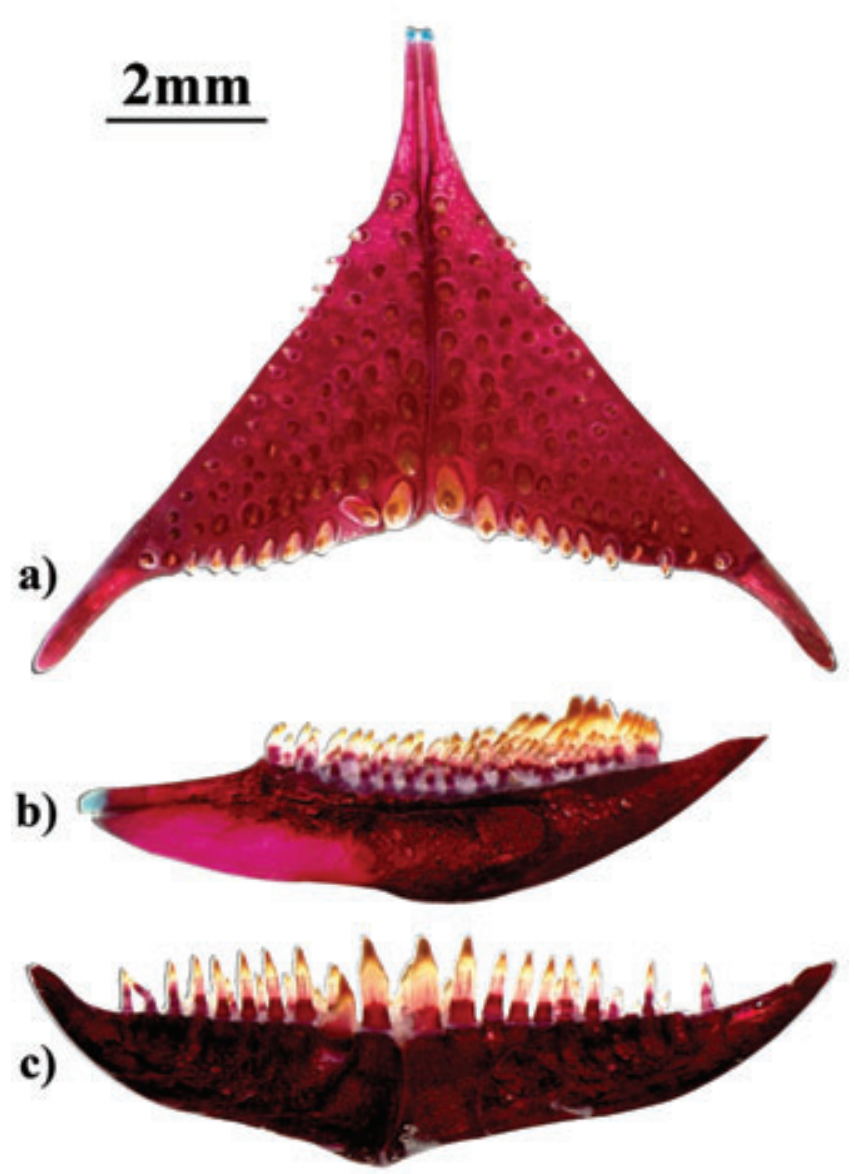

Fig. 3. Lower pharyngeal tooth plate of Crenicichla chicha, MZUSP 93683, paratype, $70.2 \mathrm{~mm} \mathrm{SL}$, in (a) occlusal, (b) lateral (anterior to left) and (c) posterior views.

teeth in inner rows inclinable, some depressible. Outer row teeth larger than inner teeth. Outer row with about 50 teeth in upper jaw ( $1 \mathrm{c} \& \mathrm{~s})$, extending for nearly the length of the alveolar ramus of the premaxilla. Upper jaw with 3-5 inner rows anteriorly, one inner row continued almost as long as outer row; 2-3 irregular inner rows in smaller specimens (up to $60 \mathrm{~mm}$ ). Outer row with 52 teeth in lower jaw, extending along $5 / 6$ of length of jaw. Lower jaw with 2-3 inner rows anteriorly, one inner row continued posteriorly for almost as long as outer row. Gill rakers externally on first gill arch 1-2 epibranchial, 1 at angle; ceratobranchial gill-rakers $6(1), 8(13), 9(10)$, or $10\left(4^{*}\right)$. Gill rakers on lower pharyngeal tooth-plate $6(1), 7\left(4^{*}\right), 8(10)$, or 9 (10). Microbranchiospines absent from all gill arches.

Lower pharyngeal tooth-plate (Fig. 3) dissected from a $70.2 \mathrm{~mm}$ specimen (MZUSP 93683), dorsoventrally compressed, with long posterior and anterior processes; tooth-plate length $79 \%$ of width; dentigerous area length $48 \%$ of width; 21 teeth in posterior row, 8-9 teeth in admedian row. Anterior teeth subconical with slightly retrorse cusp and posterior ones bigger and more robust with posterior antrorse cusp. Vertebral counts: abdominal 19, caudal 16, total 35.
Color in alcohol. Underside of head, chest, abdomen below level of pectoral-fin base and narrow zone along anal-fin base and ventral edge of caudal peduncle tan. Cheek light brown, preopercle and gill cover light grey. Snout dorsally and interorbital area dark grey. Sides and nape brownish to grey, scales almost uniformly pigmented. Lateral-line scales uniformly pigmented with same color as adjacent scales.

Preorbital stripe black and conspicuous, running from tip of lower jaw, continuing backwards onto upper lip, running below level of nostrils to orbit. Postorbital stripe appears as continuation of preorbital stripe, running behind orbit to opercular angle and onto supracleithrum with a ventral extension onto medial side of pectoral axilla.

Dark brownish, almost black narrow stripe parallels postorbital stripe, running just behind upper margin of orbit to extrascapular area; dark brownish double-marking on area corresponding to supraoccipital crest; both markings more or less masked by dark nape coloration in larger specimens. Narrow uniformly pigmented suborbital stripe running from infraorbital 3 obliquely caudoventrad toward preopercular margin.

Spots absent from pectoral-fin base. Humeral blotch absent. Dark midlateral stripe, 2-3 scales deep, continuous from supracleithrum to caudal peduncle. Seven to nine wide, relatively faded dark vertical bars, anteriormost at nape, 5-7 bars situated below dorsal fin base, last bar at caudal peduncle. Vertical bars fuse with midlateral stripe, forming a distinct midlateral row of continuous blotches, giving an overall marbled color pattern. Largest specimen examined (MZUSP 93510, $137.7 \mathrm{~mm}$ SL) with dark bars considerably more conspicuous than midlateral stripe, forming an overall barred pattern. A faint, often interrupted dark lateral band along the abdominal side present in some specimens.

Dorsal fin smoky with irregular narrow brown markings on spinous portion and up to five rows of small dots on soft portion; continuation of vertical bar pigmentation on dorsal fin base. In larger males, dorsal fin almost uniformly pigmented, with dark margin. In MZUSP 107043 (76.8 mm SL), dorsal fin without dots or dark margin but with remaining vertical bars pigmentation on fin base.

Anal fin greyish, gradually darker to lower margin. Pectoral fin hyaline, slightly dusky near base. Pelvic fin hyaline, slightly dusky on spine and anterior rays. Dark midlateral stripe continuing into middle caudal-fin rays as a lanceolate dark blotch extending across 3/4 of caudal fin length. Subdistal dark pigmentation contouring caudal fin, marginal area clear. Small scattered dark dots on dorsal and ventral caudal fin portions on most specimens. Ocellated caudal blotch black, rounded, ringed with light pigment, situated on the dorsal lobe, between rays V1 and D3.

Color in life. Based on NUP 11523, a young specimen (Fig.4) and MZUSP 93510, a mature male (Fig.5).

Young specimen. Dorsal portion of head and body yellowish green, ventral portion of head and abdominal region pale. Preorbital, postorbital and lateral band dark grey, running beyond caudal peduncle. Suborbital stripe maroon. Vertical 


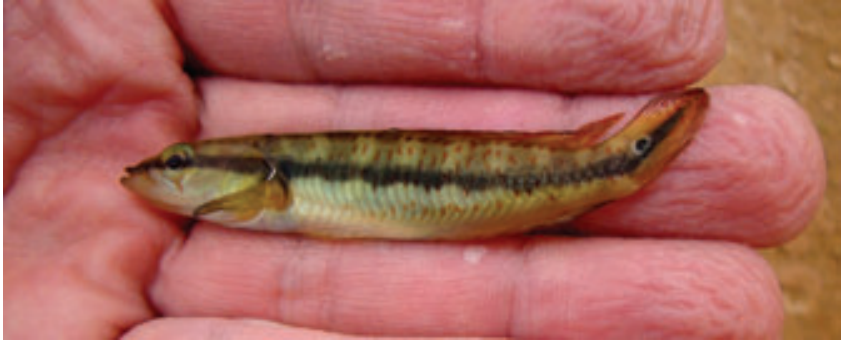

Fig. 4. Crenicichla chicha, living specimen (paratype, NUP 11523, $62.2 \mathrm{~mm}$ SL): Brazil, Mato Grosso, rio Papagaio (photo by Cláudio Zawadzki and Waldo Troy).

bars on flanks faint grey. Small orange blotches scattered on flanks. Dorsal, anal and caudal fins with red margin and reddish small dots. Caudal blotch evident with white ocellus.

Adult male. Head, nape, pectoral-fin basis, and dorsum to about the fifth dorsal spine lemon green. Sides of body bluish grey; preorbital, postorbital, lateral band, and vertical bars of flanks dark grey, less evident than in the young specimen. Irregular, narrow, wavy orange vertical stripes formed by pigmentation concentrated on scale margins distributed across flanks and caudal peduncle, relatively small anteriorly, longer and densely concentrated towards caudal peduncle, where they present a net arrangement. Pectoral fin lemon green. Pelvic spine and three anterior rays yellowish, remaining pelvic fin rays hyaline. Dorsal fin rays red, interradial membranes reddish. Distal portion of anal fin yellowish, basal portion bluish grey, with rows of red spots at basis. Caudal fin red, except for lanceolate dark grey stripe on middle caudal fin rays.

Distribution. Crenicichla chicha is known from the rio Papagaio and tributaries, itself a tributary of the rio Juruena, a major headwater of the rio Tapajós in the state of Mato
Grosso, Brazil (Fig.6). The new species was collected both above and below the Cachoeira do Utiariti, a major (about 90 meters high) waterfall in the rio Papagaio.

Etymology. The new species is named Crenicichla chicha as homage to the Paresi (or Halíti), one of the indigenous groups originally living in the Mato Grosso plateau in the region of the upper rio Juruena basin. The epithet refers to "chicha" festivities of these people, in what they meet to drink "olóniti”, a beverage made with roasted tapioca (cassava starch) of mandioca brava (bitter cassava), dance, and sing their myths. Nowadays, these celebrations occur mainly when they conclude rites of individual passage - nomination of children and pubertal girls, or within a timetable ritual, such the first harvest time of a culture of cassava. Treated as a noun in apposition.

Ecological notes. The water of the rio Papagaio is transparent and runs over a predominantly rocky bed, with swift current, and numerous rapids. One of the authors (FCTL) observed (during snorkeling) specimens of Crenicichla chicha in the rio Papagaio mainly in backwaters, or behind large boulders where water current was relatively slack. Crenicichla chicha was also observed and collected in smaller tributaries, such as the ribeirão Vinte e Cinco de Maio (which has slightly turbid waters and a predominantly sandy/muddy bottom). Like other species of Crenicichla, C. chicha is inquisitive, approaching divers, and easily collected by hand net during snorkeling. Crenicichla chicha was the only Crenicichla species occurring above the Cachoeira do Utiariti, but below this major waterfall it occurs syntopically with an undescribed species belonging to the $C$. saxatilis species group.

\section{Discussion}

As it could be expected from a highly speciose genus, there is a relatively broad morphological variation among species of

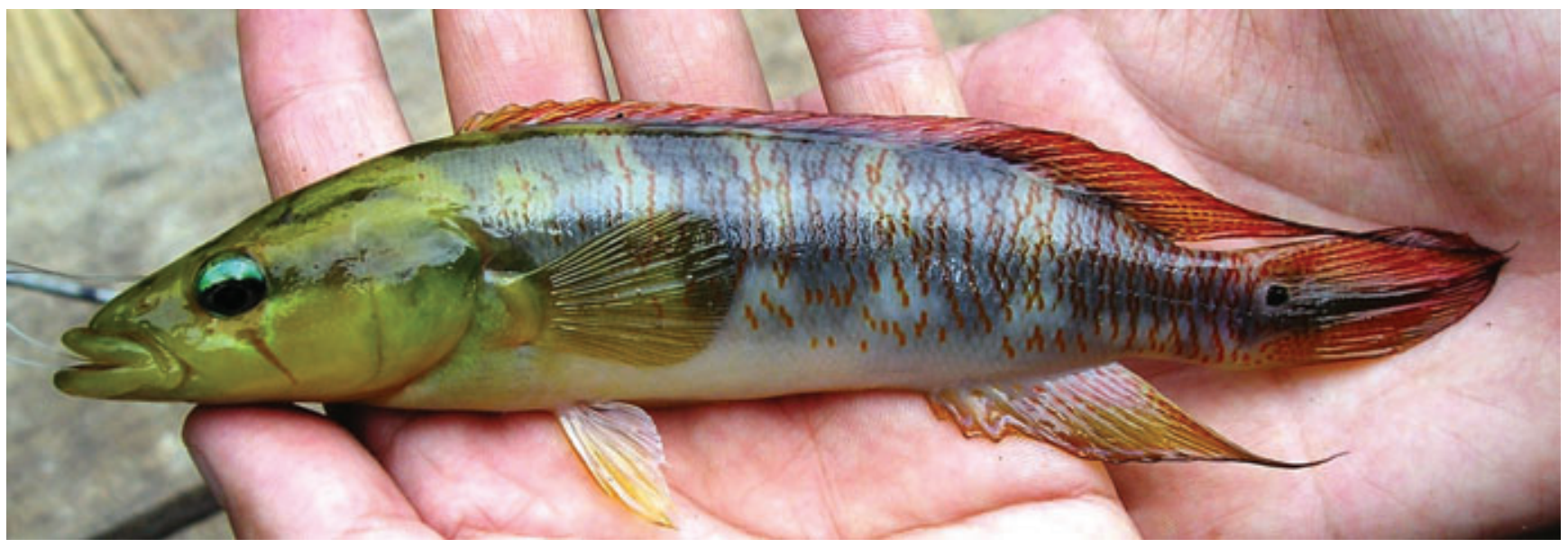

Fig. 5. Crenicichla chicha, living specimen (paratype, MZUSP 93510, 137.7 mm SL): Brazil, Mato Grosso, ribeirão Vinte e Cinco de Maio, tributary of rio Papagaio (photo by C. M. C. Leite). 


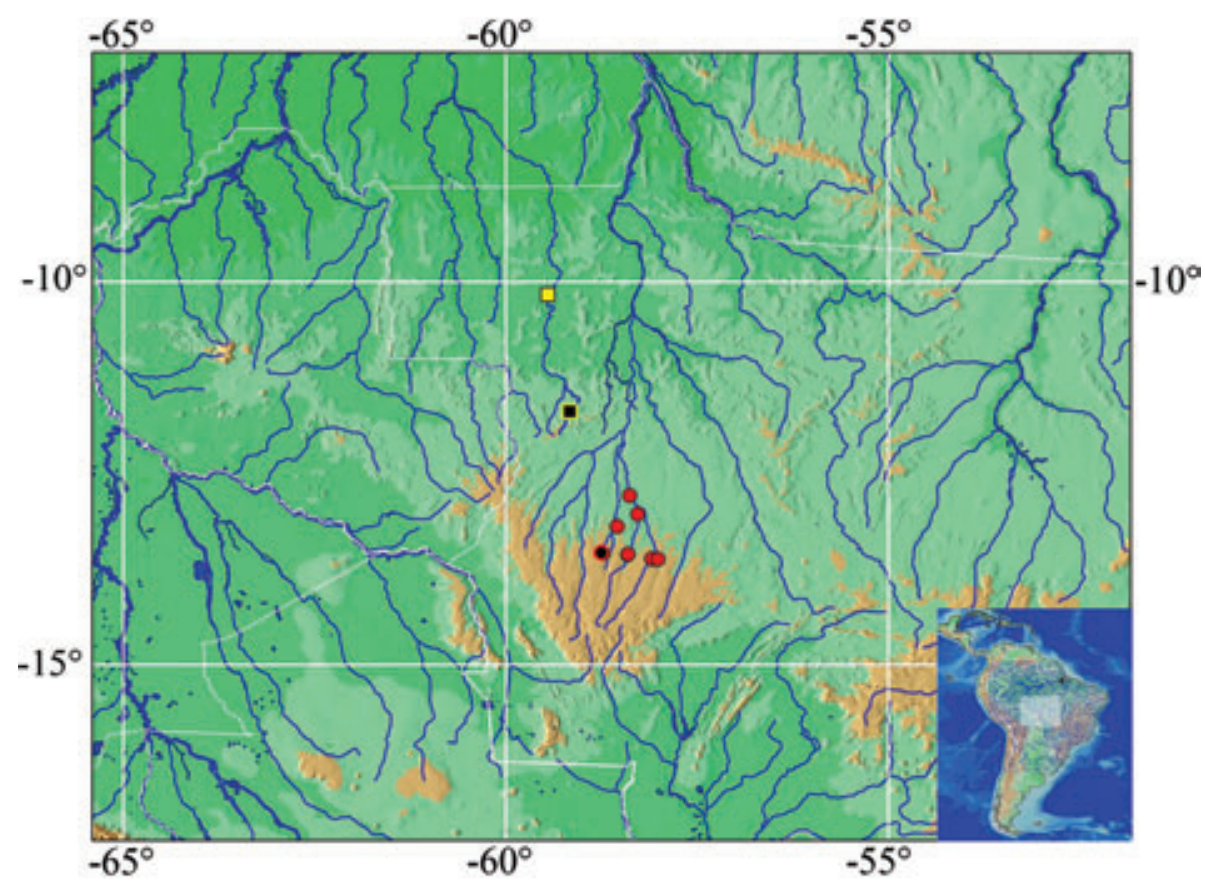

Fig. 6. Map of northern South America, showing distributions of Crenicichla chicha (circles) and C. hemera (squares). Type locality of each species as black symbols. A symbol may represent more than one collecting site.

Crenicichla, a subject which has elicited a fair amount of discussion in the literature during the last 30 years (Kullander, 1981; 1982, 1986, 1990a, b, 1991, 1997; Ploeg, 1991; Lucena \& Kullander, 1992; Kullander \& Lucena, 2006). More recently, phylogenetic molecular analyses examining the relationships of sub-sets of Crenicichla, with emphasis on species from southeastern South America, have been published (Kullander et al., 2009; Piálek et al, 2010). Kullander et al. (2009) provided the most comprehensive and updated discussion on putative monophyletic units within Crenicichla.

Some of the diagnostic character features of Crenicichla chicha, such as the smooth preopercle, the fusion between infraorbitals 3 and 4 , and the absence of microbranchiospines, do not allow a prompt allocation of $C$. chicha in any of the currently recognized groups within the genus.

The smooth preopercle is an uncommon feature among species of Crenicichla, which typically have a denticulate preopercular margin. This character state is shared with species of C. missioneira group (sensu Lucena \& Kullander, 1992; Lucena, 2007; Kullander et al., 2010), and an intraspecific variation for this feature is observed in C. jupiaensis Britski \& Luengo and C. mucuryna Ihering (H.R.V. pers. obs.). From the species of the C. missioneira group and from C. jupiaensis, C. chicha differs by having a suborbital stripe instead of suborbital stripe absent or reduced to one or a few small dots. It differs from C. mucuryna by having more scales in the E1 row (66-75 vs. 57-63 scales according to Kullander \& Lucena, 2006), and a color pattern without narrow dark vertical stripes on flanks. Another Crenicichla species possessing a smooth preopercular margin is $C$. hemera, which is discussed below. Some species of
Teleocichla also have smooth preopercle, viz. Teleocichla centrarchus Kullander, T. gephyrogramma Kullander, T. monogramma Kullander and T. centiquasma Zuanon \& Sazima.

Most African and Asian cichlids and basal Neotropical cichlids possess a series of five separate post-lacrimal infraorbital ossicles (infraorbitals 2-6). This condition is also present in the majority of species of Crenicichla, whereas in the closely related genus Teleocichla and in the majority of Neotropical cichlids and the African Tylochromis, infraorbitals 3 and four are co-ossified, as in C. hemera and C. chicha. In a few taxa infraorbitals 2, 4, and 5 are co-ossified, and in diminutive species one or more infraorbitals are lost (Kullander, 1998). Crenicichla chicha and C. hemera do not share any of the several autapomorphic character states identified in Teleocichla and which are apparently correlated with the benthic, rheophilic biology of species of that genus (Kullander, 1988). The overall similarity in morphology and colour pattern and the geographical proximity of $C$. hemera and $C$. chicha supports the interpretation of the shared presence of co-ossified infraorbitals 3-4 as a indicator of close phylogenetic relationship, unique within Crenicichla, and independently derived versus the same condition in Teleocichla, and other cichlid genera.

In most cichlids, and also most species of Crenicichla microbranchiospines are present on the $2^{\text {nd }}$ through $4^{\text {th }}$ gill arches. Microbranchiospines are frequently absent in cichlid species of small adult size, including Teleocichla and the small species of the C. wallacii group (Kullander, 1988, 1990a).

Crenicichla chicha is more similar to C. hemera than to any other species in the genus. They share the co-ossification of the infraorbitals 3 and 4, a smooth preopercle, and the 


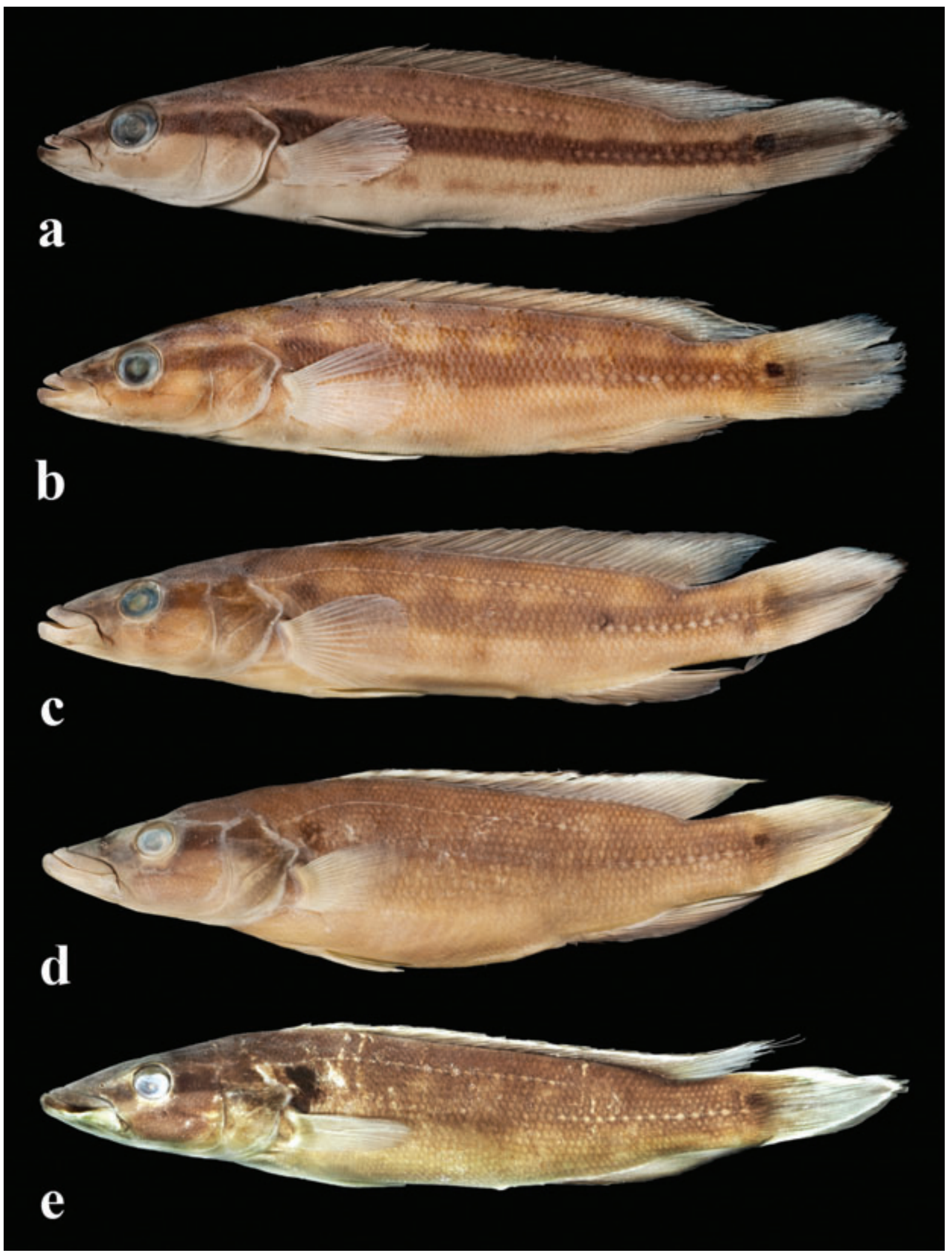

Fig. 7. Crenicichla hemera. (a) Holotype of Crenicichla hemera, MZUSP 40292, $87.3 \mathrm{~mm}$ SL, an immature female from rio Cinta Larga, rio Aripuanã drainage; (b) ZUEC 6360, $85.1 \mathrm{~mm}$ SL, rio Aripuanã at Salto das Andorinhas, rio Aripuanã drainage [inverted]; (c) ZUEC 6361127.5 mm SL, rio Aripuanã above Salto de Dardanelos/Cachoeiras das Andorinhas, rio Aripuanã drainage; (d) MZUSP 109231, 167.0 mm SL, an adult female from a small lake just below Salto de Dardanelos, rio Aripuanã drainage [inverted]; (e) Holotype of Crenicichla guentheri, INPA 2884, mm SL, $172.4 \mathrm{~mm}$ SL, an adult male from igarapé do Aeroporto, rio Aripuanã drainage (Photo by Renildo Ribeiro). 
absence of microbranchiospines. They also show some similarities in head and flank coloration: conspicuous preorbital and postorbital stripes, and the presence of a lateral band at least in juveniles. Both lack small scattered dots and horizontal stripes on flanks. Kullander (1990b) highlighted as a unique color feature of $C$. hemera the presence of a second dark lateral band along the abdominal side, fragmented and fainter than the superior one. This stripe can be seen also in some of the examined specimens of $C$. chich $a$ and in some specimens of the type series of $C$. guentheri, as a broad expansion of the ventral portion of the vertical bars on flanks, but in the majority of the material it is inconspicuous or absent.

Crenicichla hemera was described based on small specimens (45.0-96.7 mm SL), juveniles and subadults, from a headstream of the rio Cinta Larga, rio Aripuanã drainage (Kullander, 1990b). Kullander (1990b) suggested that the species possibly could grow to a larger size and that adult males might present a distinct color pattern. Ploeg (1991) described $C$. guentheri as a species belonging to the $C$. saxatilis species group species, and diagnosed it by having usually exclusively cycloid scales on the flanks and high dorsal fin ray counts. Kullander (1997: 286) examined one topotype "possibly... syntype [lapsus for paratype]" of C. guentheri (INPA 975; probably a paratype), an adult male, and in spite of the color pattern differences between this specimen and the type-series of $C$. hemera (which were ascribed to sexual dimorphism and maturity), he concluded that C. guentheri was very likely a synonym of $C$. hemera. We examined the type series of both C. hemera (holotype, Fig.7 a) and C. guentheri (holotype, Fig.7 e), plus recently collected, additional material from the rio Aripuanã drainage (see Comparative material examined). In fact, comparisons between the morphometric and meristic data (Table 2) of the type-material of each nominal species failed to demonstrate any differences.

One problematic feature that might putatively diagnose Crenicichla guentheri from C. hemera is the type of body scales present in each nominal species. Kullander (1990: 214; 1997: 286) remarked that body scales in Crenicichla hemera were mainly ctenoid, while Ploeg (1991: 34) noticed that body scales in C. guentheri specimens were mostly cycloid. Kullander (1997: 286) noticed that the tentative "syntype" (but probably not part of the material studied by Ploeg) of $C$. guentheri he examined had cycloid scales at the anterior third of the body, but mostly ctenoid scales on the posterior twothirds of the body. The re-examination of the type-series of both nominal species, and additional non-type material from the rio Aripuanã basin carried out during the present study, showed that the variation in the presence of cycloid/ctenoid scales on the flanks is large (as already pointed out by Ploeg 1991:34). For example, while the specimen ZUEC 6360 (85.1 $\mathrm{mm}$ SL) possesses a flank squamation similar to that of the holotype of C. hemera (83.7 mm SL, Fig. 8b), specimens MZUSP 37754 (93.0 mm SL, Fig. 8c), MZUSP 109231 (127.5, 167.0 [Fig. 8d] and $231.5 \mathrm{~mm} \mathrm{SL}$ ) have the anterior one-fifth to one-half of the flanks covered with cycloid scales, being more similar in this regard to the holotype of $C$. guentheri (172.4
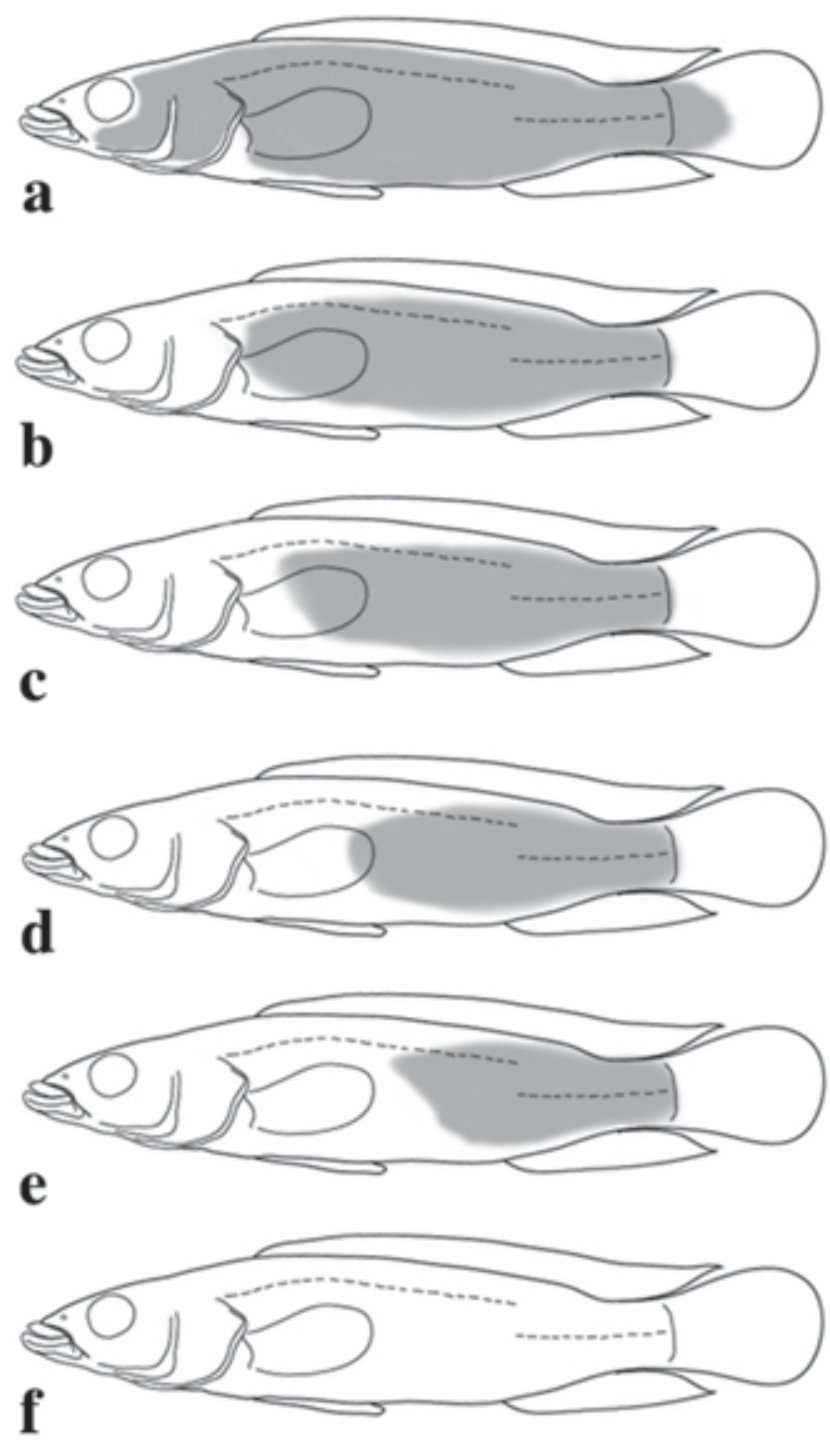

Fig. 8. Schematic drawing to show the distribution of the ctenoid scales in some Crenicichla species. Ctenoid scales grey. Dashed line represents the position of lateral line scales. a) Crenicichla macrophthalma, MZUSP 57731, $162.8 \mathrm{~mm} \mathrm{SL}$; b-e) variation found in C. hemera: b) holotype of C. hemera, MZUSP 40292, $83.7 \mathrm{~mm}$ SL; c) C. hemera, MZUSP 37754, 93.0 mm SL; d) C. hemera, MZUSP 109231, 167.0 mm SL; e) holotype of C. guentheri, INPA 2884, $172.4 \mathrm{~mm} \mathrm{SL;} \mathrm{f)} \mathrm{Crenicichla}$ johanna, MZUSP 41197, $215.0 \mathrm{~mm}$ SL.

$\mathrm{mm} \mathrm{SL}$ ) in which the anterior half of the flanks is covered by cycloid scales and the posterior half with ctenoid scales (Fig. 8e). The degree of presence of cycloid scales, however, cannot be assigned to ontogenetic change, because in some relatively large specimens from the rio Aripuanã (e.g. ZUEC 6361 127.5 and $231.5 \mathrm{~mm} \mathrm{SL}$ ) the flanks are covered entirely with ctenoid scales. We conclude that the degree of coverage with 
Table 2. Morphometry and meristics of Crenicichla hemera (holotypes of C. hemera and C. guentheri, and the range of all specimens examined). $\mathrm{N}=$ Number of specimens, $\mathrm{SD}=$ standard deviation, frequencies in parentheses.

\begin{tabular}{|c|c|c|c|c|c|c|c|}
\hline \multirow[b]{2}{*}{ Measurements } & \multirow{2}{*}{$\begin{array}{l}\text { Holotype } \\
\text { C. hemera }\end{array}$} & \multirow{2}{*}{$\begin{array}{c}\text { Holotype } \\
\text { C. guentheri }\end{array}$} & \multicolumn{5}{|c|}{ Range } \\
\hline & & & $\mathrm{N}$ & Min & Max & Mean & SD \\
\hline \multirow[t]{2}{*}{ Standard length (mm) } & 86.8 & 172.3 & 26 & 45.0 & 231.5 & 114.8 & - \\
\hline & \multicolumn{7}{|c|}{ Percents of Standard length } \\
\hline Body depth & 21.2 & 20.0 & 26 & 18.7 & 22.9 & 20.5 & 1.2 \\
\hline Head length & 32.1 & 33.0 & 26 & 29.5 & 33.6 & 32.5 & 0.8 \\
\hline Head depth & 14.9 & 13.0 & 26 & 12.1 & 16.3 & 14.0 & 1.2 \\
\hline Orbital diameter & 8.6 & 6.8 & 26 & 5.6 & 10.4 & 8.2 & 1.2 \\
\hline Interorbital width & 5.4 & 6.0 & 26 & 4.2 & 7.2 & 5.3 & 0.7 \\
\hline Snout length & 8.7 & 10.8 & 26 & 7.3 & 11.9 & 9.5 & 1.1 \\
\hline Upper jaw length & 10.5 & 11.8 & 26 & 8.9 & 12.9 & 10.5 & 1.1 \\
\hline Lower jaw length & 14.4 & 16.5 & 26 & 13.6 & 17.4 & 15.0 & 1.0 \\
\hline Caudal peduncle depth & 10.5 & 9.6 & 26 & 9.0 & 10.9 & 10.0 & 0.5 \\
\hline Caudal peduncle length & 12.4 & 12.1 & 26 & 11.5 & 13.4 & 12.3 & 0.4 \\
\hline Last dorsal spine length & 12.1 & 9.4 & 25 & 8.2 & 14.6 & 11.5 & 1.7 \\
\hline Pectoral fin length & 18.7 & 17.9 & 26 & 15.2 & 24.2 & 18.7 & 1.9 \\
\hline Counts & & & $\mathrm{N}$ & \multicolumn{4}{|c|}{ Range } \\
\hline E1 row scales & 64 & 62 & 26 & \multirow{2}{*}{\multicolumn{4}{|c|}{$\begin{array}{c}58 \text { (1), } 59 \text { (1), } 60 \text { (7), } 61 \text { (7), } 62 \text { (4), } 63 \text { (2), } 64 \text { (2), } 65 \text { (2), } \\
22 / 12 \text { (5), } 22 / 13 \text { (4), 23/11 (5), } 23 / 12 \text { (5), 23/13 (2), } 24 / 11 \text { (2), } \\
24 / 12 \text { (2) }\end{array}$}} \\
\hline Lateral line scales & 23/13 & $22 / 13$ & 25 & & & & \\
\hline Dorsal fin & XX.14 & XX.14 & 26 & \multicolumn{4}{|c|}{ XIX.13 (1), XX.13 (5), XX.14 (13), XXI.13 (2), XXI.14 (5) } \\
\hline Anal fin & III.10 & III.11 & 26 & \multicolumn{4}{|c|}{ III.9 (1), III.10 (13), III.11 (11), III.12 (1) } \\
\hline Pectoral fin rays & 16 & 16 & 26 & \multicolumn{4}{|c|}{$16(23), 17(3)$} \\
\hline Gill rakers $1^{\text {st }}$ ceratobranchial & 10 & 10 & 26 & \multicolumn{4}{|c|}{$8(6), 9(5), 10(12), 11(3)$} \\
\hline
\end{tabular}

cycloid/ctenoid scales is a polymorphic feature within $C$. hemera, and cannot be used to diagnose C. guentheri.

Also, as earlier advanced by Kullander (1997) based on the examination of one topotypical specimen of C. guentheri, all the type material examined of C. guentheri possesses a smooth preopercle. Finally, Kullander (1997) also noticed the presence of co-ossified infraorbitals 3 and 4 in the specimen of $C$. guentheri that he examined, and we confirmed the co-ossification of the same bones in the same specimen, and additionally, in the holotype (INPA 2884) and paratypes (INPA 1493, INPA 1495) of $C$. guentheri, as well as some of the non-types MZUSP 37754, MZUSP 109231, ZUEC 6360, and ZUEC 6361 (this character cannot be distinguished in all alcohol-preserved specimens, only in the ones that are relatively faded and/or dehydrated). We thus concur with Kullander (1997) and confirm the synonymization of $C$. guentheri with C. hemera.

The coloration of $C$. hemera, based on the examination of 69 specimens, 25.7-231.5 mm SL, shows a remarkable ontogenetic change from juveniles to adults. This change can be observed in specimens from approximately $80 \mathrm{~mm}$ of SL. Juveniles and subadults have a conspicuous lateral band 2-3 scales wide, pre- and postorbital stripes and caudal blotch without light ring or masked by the expansion of lateral band pigmentation (Fig. 7a). In faded or poorly preserved specimens, the lateral band can be faint and indistinct (Fig. 7b). The dorsal, anal and caudal fins present a light submargin and dark margin, and dorsal fin with many small brown dots. Adults usually have preorbital stripe masked by dark snout pigmentation and an inconspicuous lateral band, which is sometimes totally absent (Fig. 7c -e). The dorsal fin lacks small dots, the caudal blotch is faint, almost indistinct, and the light submargin and dark margin are more evident than in subadults. In mature females, the light submarginal area is slightly wider than in males. Except for the rounded abdomen of mature females, no pronounced sexual dimorphism was observed.

Ploeg (1991) allocated C. guentheri into the C. saxatilis species group because of the presence of a humeral blotch. A dark blotch in the region just above the pectoral fin is indeed present in most specimens of $C$. hemera, but it seems to be actually a remnant portion of the lateral stripe rather than the typical distinct humeral blotch of the species belonging to the $C$. saxatilis species group. On the other hand, fourteen specimens (107.0-231.5 mm SL) show a pronounced humeral darkening. This kind of darkening can be noted in other Crenicichla, such the C. lugubris related species (Ploeg, 1991, Kullander, 1997) that undergo a similar ontogenetic change of color pattern. However, other diagnostic character states of Crenicichla hemera do not point to a close affinity either to species belonging to the $C$. saxatilis species group or to the $C$. lugubris species group, particularly the smooth preopercle and the E1 counts (too high for a species belonging to the $C$. saxatilis species group and too low for one belonging to the $C$. lugubris species group).

We concur with Kullander $(1990 \mathrm{~b}, 1997)$ in considering $C$. hemera a distinctive species, not assignable to any of the currently recognized species groups within the genus. On other hand, and as pointed above, there is a close resemblance between $C$. hemera and $C$. chicha, which seems to indicate that both species are closely related, putatively sister taxa.

Crenicichla hemera is also a rapids dwelling fish (Kullander, 1990b; FCTL, pers. obs., rio Aripuanã, November 
2005) that occurs both above and below the salto do Dardanelos/salto das Andorinhas, a major (about 120 meters high) waterfall in the rio Aripuanã drainage, rio Madeira basin. Interestingly, $C$. hemera and $C$. chicha occur in adjoining shield-draining river systems, respectively the rio Aripuanã and the rio Juruena (which, after joining the rio Teles Pires, becomes the rio Tapajós) (Fig. 6). Similarly, Steindachnerina fasciata (Curimatidae) is also recorded from clear-water, shield tributaries of the upper rio Madeira and upper rio Tapajós basin (Netto-Ferreira \& Vari, 2011: 527-528). In fact, fish taxa displaying shield patterns in northern cis-andean South America generally occur in adjoining river systems but not in the lowlands, indicating that headwater river captures in shield areas, rather than dispersion via lowland areas was the prevailing mechanism allowing range expansions (and eventually allopatric speciation) across distinct river systems (Lima \& Ribeiro, 2011).

Comparative material examined. Crenicichla hemera. All from Brazil, Mato Grosso, rio Aripuanã drainage: Type series of Crenicichla hemera: MZUSP 40292, holotype, $87.3 \mathrm{~mm} \mathrm{SL}$, headwater stream tributary to Cinta Larga where crossed by the road BR-174, $41 \mathrm{~km}$ from Juína, 13 Oct 1989, S.O. Kullander et al. NRM 26094, paratypes, 7, 45.0-96.7 mm SL, same data as holotype. Type series of Crenicichla guentheri: INPA 2884, holotype, 172.4 mm SL, igarapé do Aeroporto, Humboldt, 14 Nov 1976, Equipe Ictiologia INPA. Paratypes: INPA 975, 9, 40.4-111.0 mm SL, same data as holotype. INPA 1489, 14, 25.7-39.64 mm SL, igarapé Guaribal, tributary to rio Aripuanã, 10 Nov 1976, INPA. INPA 1493, 4, 53.5-118,9 mm SL, rio Aripuanã, 3 km below Cachoeira de Dardanelos, Humboldt, 7 Nov 1976, Equipe Ictiologia INPA. INPA 1494, 14, 87.2-166.3 mm SL, rio Aripuanã, near Cachoeira Dardanelos, 26 Sep 1975, Martinho. INPA 1495, 3, 160.1-165.9 mm SL, igarapé Genipapo, st. 11, at 70 km near Cachoeira Dardanelos, 14 Nov 1976, Equipe Ictiologia INPA. INPA 2882, 2, 97.4-115.5 mm SL, igarapé da Chaparé, 11 Nov 1976, INPA. INPA 2823, 1, 74.4 mm SL, INPA 1435, 50.6-80.7 mm SL, igarapé do Aeroporto, above Cachoeira de Dardanelos, Humboldt, 9 Nov 1976, Equipe Ictiologia INPA. Additional material (non-types): MZUSP 37754, 1, 93.0 mm SL, Aripuanã , Igarapé da Chapada, tributary of igarapé do Aeroporto, Humboldt, 11 Nov 1976, Equipe MZUSP \& INPA. MZUSP 101041, 1, 228.0 mm SL, Aripuanã, rio Aripuanã, below Salto de Dardanelos, Porto do Onofre, 10¹0'06”'S 59²6’50”W, 4 Jul 2004, F. A. Machado, C. M. C. Leite \& F. R. Rosa. MZUSP 109231, 3, 128.7-215.0 mm SL, Aripuanã, rio Aripuanã, small lake just below Salto de Dardanelos, 109'47’S 59²6’57’'W; 25 Sept 2004, F. A. Machado, C. M. C. Leite, F. R. Rosa \& N. E. Silva. ZUEC 6360, 1, $85.1 \mathrm{~mm}$ SL, Aripuanã, rio Aripuanã at Salto das Andorinhas (cofferdam), 109’54”S 59²7’26”W, 20 Sept 2004, F. A. Machado, C. M. C. Leite, F. R. Rosa \& N. E. Silva. ZUEC 6361, 2, 127.5-231.5 mm SL, Aripuanã, rio Aripuanã above Salto de Dardanelos/Cachoeiras das Andorinhas, 15 Sep 2004, F. A. Machado, C. M. C. Leite, F. R. Rosa \& N. E. Silva.

Other comparative material. Crenicichla britskii. MZUSP 41266, 13, 58.1-101.0 mm; 1 c\&s, 89.2 mm SL. Crenicichla compressiceps. MZUSP 41174, 277, 20.0-43.0 mm, 4 c\&s, 33.5, 35.8, 38.5 and $41.5 \mathrm{~mm}$ SL. Crenicichla empheres. MCP 40176, paratype, 1 c\&s, 93.2 mm SL. Crenicichla haroldoi. MZUSP 16038, 23, 46.4-105.2 mm SL; 1 c\&s, 107.5 mm SL. Crenicichla hu AI 266, 1 c\&s, 92.2 mm SL. Crenicichla iguapina. MZUSP 78701, 6, 58.5-93.4 mm; 1 c\&s, 64.7 mm SL. Crenicichla iguassuensis. NUP 1796, 1 c\&s, 87.7 mm SL. Crenicichla inpa. MZUSP 107089, 19, 30.0-91.8 mm; 1 c\&s, 74.5 mm SL. Crenicichla jaguarensis. MZUSP 16045, 26, 65.9-160.1 mm SL, 1 c\&s, 89.5 mm SL. Crenicichla johanna. MZUSP 41197, 9, 88.6-215.0 mm; 1 c\&s, 103.0 mm SL; MZUSP 108415 (1 esq, 240.0 mm SL. Crenicichla labrina. MZUSP 41202, 47, 25.0-167.0 mm; 1 c\&s, 170.0 mm SL. Crenicichla lepidota. MZUSP 16025, 6, 72.1-111.3, 1 c\&s, 77.6 mm SL. Crenicichla lugubris. MZUSP 89526, 1 esq, $200.0 \mathrm{~mm}$ SL. Crenicichla macrophthalma. MZUSP 57731, 1, 162.8 mm SL; MZUSP 105713, 2, 120.0-142.5 mm SL; 1 c\&s, 117.0 mm SL. Crenicichla niederleinii. NUP 3661, 4, 57.4-84.2 mm SL; 1 c\&s, 92.78 mm SL. Crenicichla punctata. MCP 13187, 1 of 2 c\&s, 82.0 mm SL. Crenicichla regani. MZUSP 39049, 57; 2 c\&s, 49.3 mm SL, female, 57.2 mm SL, male. Crenicichla tesay. NUP 1676, 27, 66.0-141.4 mm SL; 1 c\&s, 96.0 mm SL. Crenicichla yaha. NUP 2966, 23, 75.5-111.5 mm SL; 1 c\&s, 92.7 mm SL. Crenicichla ypo. AI 266, 1 c\&s, 95.3 mm SL. Teleocichla proselytus. MZUSP 21852, 23; 1 c\&s, 56.6 mm SL.

\section{Acknowledgements}

The first author is grateful to Lúcia R. Py-Daniel and Marcelo Rocha (INPA), Roberto E. Reis and Carlos A. S. Lucena (MCP), Cláudio H. Zawadzki and Carla S. Pavanelli (NUP) for assistance while visiting their institutions. Ricardo Kawada for taking the composite photos of pharyngeal tooth plate and the infraorbitals series, to Leandro Sousa and Eduardo Baena for helping with image processing, to Renildo Oliveira for sending pictures of the type material of Crenicichla guentheri, to Waldo P. Troy for the photo of a recently collected paratype, and to José Birindelli for multiple suggestions along the development of the present study. Special thanks are due to Francisco A. Machado, for organizing the field expedition to the rio Papagaio, when most of the type-material of Crenicichla chicha was collected. We are also grateful to C. M. C. Leite and N. E. Silva for assistance during the field trip. H. R. V. and F. C. T. L. were funded by FAPESP (grant 2008/56130-1 and 2007/02978-7, respectively).

\section{Literature Cited}

Barel C. D. N., M. J. P. Van Oijen, F. Witte \& E. Witte-Mass. 1977. An introduction to the taxonomy and morphology of the haplochromine cichlids from Lake Victoria. Netherlands Journal of Zoology, 27: 333-389.

Casciotta, J. R., A. E. Almirón \& S. E. Gómez. 2006. Crenicichla yaha sp. n. (Perciformes: Labroidei: Cichlidae), a new species from the río Iguazú and arroyo Urugua-í basins, northeastern Argentina. Zoologische Abhandlungen (Dresden), 56: 107-112.

Casciotta, J. R., A. E. Almirón, L. Piálek, S. E. Gómez \& O. Øíèan. 2010. Crenicichla ypo (Teleostei: Cichlidae), a new species from the middle Paraná basin in Misiones, Argentina. Neotropical Ichthyology, 8: 643-648.

Kullander, S. O. 1981. Cichlid fishes from the La Plata basin. Part I. Collections from Paraguay in the Muséum d'Histoire naturelle de Genève. Revue suisse de Zoologie, 88: 675-692.

Kullander, S. O. 1982. Cichlid fishes from the La Plata basin. Part III. The Crenicichla lepidota species group. Revue suisse Zoologie, 89: 627-661. 
Kullander, S. O. 1986. The cichlid fishes of the Amazon river drainage of Peru. Swedish Museum of Natural History, Stockholm, 431p.

Kullander, S. O. 1988. Teleocichla, a new genus of South American rheophilic cichid fishes with six new species. Copeia, 1988: 196-230.

Kullander, S. O. 1990a. A new species of Crenicichla (Teleostei: Cichlidae) from the rio Tapajós, Brazil, with comments on interrelationships of small crenicichline cichlids. Ichthyological Exploration of Freshwaters, 1: 85-94.

Kullander, S. O. 1990b. Crenicichla hemera (Teleostei: Cichlidae), a new cichlid species from the rio Aripuanã drainage, Mato Grosso, Brazil. Ichthyological Exploration of Freshwaters, 1: 213-218.

Kullander, S. O. 1991. Crenicichla phaiospilus, and C. percna, two new species of pike cichlid (Teleostei: Cichlidae) from the rio Xingu, Brazil. Ichthyological Exploration of Freshwaters, 2: 351-360.

Kullander, S. O. 1997. Crenicichla rosemariae, a new species of pike cichlid (Teleostei, Cichlidae) from the upper rio Xingu drainage, Brazil. Ichthyological Exploration of Freshwaters, 7: 279-287.

Kullander, S. O. 1998. A phylogeny and classification of the South American Cichlidae. Pp. 461-498. In: Malabarba, L. R., R. E. Reis, R. P. Vari, Z. M. S. Lucena \& C. A. S. Lucena (Eds.). Phylogeny and Classification of Neotropical Fishes. Porto Alegre, Edipucrs, 603p.

Kullander, S. O. 2003. Family Cichlidae. Pp. 605-654. In: Reis, R. E., S. O. Kullander \& C. J. Ferraris Jr. (Orgs.). Check list of the freshwater fishes of South and Central America. Edipucrs, Porto Alegre, Edipucrs, 729p.

Kullander, S. O. 2009. Crenicichla mandelburgeri, a new species of cichlid fish (Teleostei: Cichlidae) from the Paraná river drainage in Paraguay. Zootaxa, 2006: 41-50.

Kullander, S. O. \& C. A. S. Lucena. 2006. A review of the species of Crenicichla (Teleostei, Cichlidae) from the Atlantic coastal rivers of southeastern Brazil from Bahia to Rio Grande do Sul States, with descriptions of three new species. Neotropical Ichthyology, 4: 127-46.

Kullander, S. O., M. Norén, G. B. Friðriksson \& C. A. S. Lucena. 2009. Phylogenetic relationships of species of Crenicichla (Teleostei: Cichlidae) from southern South America based on the mitochondrial cytochrome b gene. Journal of Zoological Systematics and Evolutionary Research, 48: 248-258.
Lima, F. C. T. \& A. C. Ribeiro. 2011. Continental-scale tectonic controls of biogeography and ecology. Pp. 145-164. In: J. S. Albert \& R. E. Reis (Eds.). Historical Biogeography of Neotropical Freshwater Fishes. Berkeley, University of California Press, 408p.

Lucena, C. A. S. 2007. Two new species of the genus Crenicichla Heckel, 1840 from the upper rio Uruguay drainage (Perciformes: Cichlidae). Neotropical Ichthyology, 5: 449-456.

Lucena, C. A. S. \& S. O. Kullander. 1992. The Crenicichla (Teleostei: Cichlidae) species of the Uruguai River drainage in Brazil. Ichthyological Exploration of Freshwaters, 3: 97-160.

Montaña, C. G., H. López-Fernández \& D. C. Taphorn. 2008. A new species of Crenicichla (Perciformes: Cichlidae) from the Ventuari River, Upper Orinoco River Basin, Amazonas State, Venezuela. Zootaxa 1856: 33-40.

Netto-Ferreira, A. L. \& R. P. Vari. 2011. New species of Steindachnerina (Characiformes: Curimatidae) from the rio Tapajós, Brazil, and review of the genus in the rio Tapajós and rio Xingu basins. Copeia, 2011: 523-529.

Pellegrin, J. 1904. Contribution à l'étude anatomique, biologique et taxinomique des poissons de la famille des Cichlidés. Memoires de la Société Zoologique de France, 16: 41-400.

Piálek, L., O. Rícan, J. R. Casciotta \& A. E. Almirón. 2010. Crenicichla hu, a new species of cichlid fish (Teleostei: Cichlidae) from the Paraná basin in Misiones, Argentina. Zootaxa, 2537: 33-46.

Ploeg, A. 1991. Revision of the South American cichlid genus Crenicichla Heckel, 1840 with descriptions of fifteen new species and considerations on species groups, phylogeny and biogeography (Pisces, Perciformes, Cichlidae). Akademisch Proefschrift, Universiteit van Amsterdam, 152p.

Regan, C. T. 1905. A revision of the fishes of the South-American cichlid genera Crenacara, Batrachops, and Crenicichla. Proceedings of the Zoological Society of London, 1: 152-168.

Regan, C. T. 1913. A synopsis of the cichlid fishes of the genus Crenicichla. Annals and Magazine of Natural Hististory, 11: 498-504.

Taylor, W. R. \& G. C. van Dyke. 1985. Revised procedures for staining and clearing small fishes and other vertebrates for bone and cartilage study. Cybium, 9: 107-119.

Submitted June 13, 2011

Accepted March 16, 2012

Published June 29, 2012 